\title{
Difference in the Effects of Acetazolamide and Ammonium Chloride Acidosis on Ventilatory Responses to $\mathrm{CO}_{2}$ and Hypoxia in Humans
}

\author{
Hirokazu ToJima, Fumio Kunitomo, Shinya OKITA, \\ Yasutoshi Yuguchi, Koichiro Tatsumi, Hiroshi KImURA, \\ Takayuki KurIYAma, Shohei WatanaBe, and Yoshiyuki HondA* \\ Department of Chest Medicine, Institute of Pulmonary Cancer \\ Research, and *Department of Physiology, Faculty of Medicine, \\ Chiba University, Chiba, 280 Japan
}

\begin{abstract}
The effects of acetazolamide, a potent carbonic anhydrase inhibitor, and ammonium chloride $\left(\mathrm{NH}_{4} \mathrm{Cl}\right)$ on arterial blood gas tension, resting ventilation, and ventilatory responses to $\mathrm{CO}_{2}$ (HCVR) and hypoxia (HVR) were studied in healthy male subjects. Both drugs induced chronic metabolic acidosis with the reduction in plasma bicarbonate by a mean of $7.0 \pm 2.0$ (S.D.) $\mathrm{mm}$ after acetazolamide and by $5.6 \pm 1.8 \mathrm{~mm}$ after $\mathrm{NH}_{4} \mathrm{Cl}$. The ratio in the decrement of $\mathrm{Pa}_{\mathrm{CO}_{2}}$ to that of plasma bicarbonate $\left(\triangle \mathrm{Pa}_{\mathrm{CO}_{2}} / \Delta\left[\mathrm{HCO}_{3}^{-}\right]\right)$was 1.51 in the former and 0.98 in the latter. Both drugs increased inspiratory minute ventilation $\left(\dot{V}_{\mathrm{I}}\right)$ predominantly due to increased tidal volume $(V T)$ with acetazolamide and to increased respiratory frequency $(f)$ with $\mathrm{NH}_{4} \mathrm{Cl}$. In $\mathrm{HCVR}$, the increments in $\mathrm{CO}_{2}$ ventilation slope and in ventilation at $P_{\mathrm{ET}_{\mathrm{CO}_{2}}} 60 \mathrm{mmHg}$ after drug administration were $0.77 \pm 0.51 l \cdot \mathrm{min}^{-1} \cdot \mathrm{mmHg}^{-1}$ and $20.0 \pm 11.2 \mathrm{l} / \mathrm{min}$ with acetazolamide and $0.59 \pm 0.40 \mathrm{l} \cdot \mathrm{min}^{-1} \cdot \mathrm{mmHg}^{-1}$ and $8.0 \pm 2.8 \mathrm{l} / \mathrm{min}$ with $\mathrm{NH}_{4} \mathrm{Cl}$, respectively. On the other hand, HVR both in terms of $\Delta \dot{V} \mathrm{I} / \Delta \mathrm{Sa}_{\mathrm{O}_{2}}$ slope and of ventilation at $\mathrm{Sa}_{\mathrm{O}_{2}} 75 \%$ significantly increased after $\mathrm{NH}_{4} \mathrm{Cl}$ but not after acetazolamide administration. Thus, augmented $V \mathrm{~T}$ and HCVR in the acetazolamide group and increased $f$ and HVR in the $\mathrm{NH}_{4} \mathrm{Cl}$ group suggested that the central chemosensitive mechanism in the former and the peripheral chemosensitive mechanism in the latter may predominantly be responsible for the elevated ventilatory activities.
\end{abstract}

Key words: acetazolamide, ammonium chloride, hypercapnic ventilatory response, hypoxic ventilatory response, metabolic acidosis.

Acetazolamide is known as a potent inhibitor of carbonic anhydrase, which catalyzes the hydration reaction of $\mathrm{CO}_{2}$ to form carbonic acid. Carbonic anhydrase is located at the luminal membrane of the proximal tubular epithelial cells. Hence,

Received for publication February 6, 1986 
the lack of $\mathrm{H}^{+}$supplied from tubular cells to the tubular lumen results in the loss of sodium bicarbonate from the glomerular filtrate to the urine, thus leading to metabolic acidosis (MAREN, 1967). Besides this influence on renal function, retarded hydration rate of $\mathrm{CO}_{2}$ affects the $\mathrm{CO}_{2}$ transport process in the various tissues containing carbonic anhydrase, and particularly in the central nervous system (HASAN and KAZEMI, 1976; JAVAHERI et al., 1984).

On the other hand, the administration of ammonium chloride is tantamount to the administration of hydrochloric acid itself because ammonium ions are rapidly converted to urea and hydrogen ions by the liver (HARRINGTON and COHEN, 1982). The buffer base including bicarbonate in the body fluid is greatly diminished and metabolic acidosis develops.

Ventilatory adjustment in response to metabolic acidosis is also known to occur in order to maintain the acid-base homeostasis of body fluid (PETERS, 1917). Therefore, alterations in the control function of the respiratory system can be expected.

Because the physiological mechanisms to induce metabolic acidosis in the two chemical agents are different, the present experiments were undertaken to compare the effects of both drugs on blood gases, pulmonary function, and chemical control of breathing.

\section{MATERIALS AND METHODS}

Eleven healthy adult men, aged $22-59$ years (mean \pm S.D.; $33 \pm 10.4$ ), were examined. The following studies were performed before and 4 days after acetazolamide administration at a dose of $500 \mathrm{mg}$ once a day; (1) pulmonary function tests, (2) arterial blood gas analysis, (3) resting ventilation and metabolism, (4) hypercapnic ventilatory response (HCVR), and (5) hypoxic ventilatory response (HVR). In 6 of the 11 subjects, the same studies were performed before and 3 days after $\mathrm{NH}_{4} \mathrm{Cl}$ administration at a dose of $8 \mathrm{~g}$ daily and the results were compared with those of acetazolamide administration.

Pulmonary function tests were performed to determine vital capacity (VC), forced expiratory volume in $1 \mathrm{~s}\left(\mathrm{FEV}_{1.0}\right)$, and functional residual capacity (FRC). Arterial blood gases $\left(\mathrm{Pa}_{\mathrm{CO}_{2}}, \mathrm{~Pa}_{\mathrm{O}_{2}}\right.$, and $\left.\mathrm{pH}\right)$ were measured with samples taken from the subjects sitting at rest and breathing room air by IL 1303. Plasma bicarbonate concentration $\left(\left[\mathrm{HCO}_{3}^{-}\right]\right)$was calculated by the Henderson-Hasselbalch equation. Resting ventilation and metabolism were measured in 7 subjects. Inspiratory minute ventilation $\left(\dot{V}_{\mathrm{I}}\right)$, tidal volume $(V \mathrm{~T})$, respiratory frequency $(f)$, inspiratory time $\left(T_{\mathrm{I}}\right)$, expiratory time $\left(T_{\mathrm{E}}\right)$, duty cycle $\left(T_{\mathrm{I}} / T_{\mathrm{T}}\right)$, and mean inspiratory flow $\left(V_{\mathrm{T}} / T_{\mathrm{I}}\right)$ at rest were determined in the subjects while breathing through a mouthpiece. Oxygen consumption $\left(\dot{V}_{\mathrm{O}_{2}}\right)$ and $\mathrm{CO}_{2}$ production $\left(\dot{V}_{\mathrm{CO}_{2}}\right)$ were measured by an Aerobics Processor (Sanei), consisting of a hot-wire flow meter and a $\mathrm{CO}_{2}-\mathrm{O}_{2}$ analyzer (1H21).

HCVR curve was obtained by Read's rebreathing method, with subjects in a 
sitting position. The subjects rebreathed $5-6 l$ of $7-8 \% \mathrm{CO}_{2}$ in an $\mathrm{O}_{2}$ mixture through a closed-circuit system containing a low-resistance one-way Lloyd valve. During rebreathing, end-tidal $P_{\mathrm{CO}_{2}}\left(P_{\mathrm{ET}_{\mathrm{CO}_{2}}}\right)$ and end-tidal $P_{\mathrm{O}_{2}}\left(P_{\mathrm{ET}_{\mathrm{O}_{2}}}\right)$ were monitored by a rapid response analyzer (Sanei, 1H21). Respiratory flow was measured with a hot-wire flow meter (Minato, RF-H) and $V_{\mathrm{T}}, T_{\mathrm{I}}, T \mathrm{E}$, and $T \mathrm{~T}$ were electrically computed by an analog calculator from the flow signal. $\dot{V}_{I}$ was obtained as the average of three successive breaths. All the measured variables were fed into a signal processor (Nihon Denki-Sanei, 7T17) and $\mathrm{CO}_{2}$ response lines were analyzed on-line. The test was usually terminated within 3-4 min after confirming an alveolar plateau in the $P_{\mathrm{ET}_{\mathrm{CO}}}$ recording. The $\mathrm{CO}_{2}$ response was evaluated by the slope of linear regression between $\dot{V}_{\mathrm{I}}$ and $\mathrm{PET}_{\mathrm{CO}_{2}}$.

The HVR curve was obtained by the progressive isocapnic hypoxia method. The subjects rebreathed in a closed-circuit where a container of $\mathrm{CO}_{2}$ absorber was connected by a bypass. $P_{\mathrm{ET}_{\mathrm{O}_{2}}}$ was gradually decreased at the rate of about

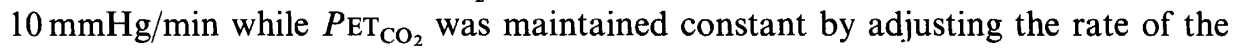
bypass flow. Oxygen saturation $\left(\mathrm{Sa}_{\mathrm{O}_{2}}\right)$ was also continuously measured by an ear oximeter (BIOX IIA). As well as HCVR measurement, respiratory flow, $V \mathrm{~T}, T \mathrm{I}$, $T \mathrm{E}$, and $T \mathrm{~T}$ were electrically computed and all the measured variables, including $\dot{V}_{\mathrm{I}}$ and $\mathrm{Sa}_{\mathrm{O}_{2}}$, were processed by the signal processor. Hypoxic response lines were evaluated from the linear regression between $\dot{V}_{\mathrm{I}}$ and $S \mathrm{a}_{\mathrm{O}_{2}}$.

After acetazolamide administration, $\mathrm{HVR}$ was measured at two $\mathrm{PET}_{\mathrm{CO}_{2}}$ levels. This was necessary because drug-induced hyperventilation was accompanied by hypocapnia, which is known to attenuate HVR. In the study after acetazolamide, the first measurement was made at the $\mathrm{PET}_{\mathrm{CO}_{2}}$ level of the drug induced hypocapnia (defined as "hypocapnic condition") and the second measurement was made at the same $P_{\mathrm{ET}_{\mathrm{CO}}}$ level as observed before drug administration (defined as "normocapnic condition"). During the normocapnic HVR measurement, the $P_{\mathrm{ET}_{\mathrm{CO}}}$ level was raised, by adjusting the bypass flow to the $\mathrm{CO}_{2}$ absorber, to the level determined before acetazolamide administration in each subject. In the $\mathrm{NH}_{4} \mathrm{Cl}$ study, because the degree of $\mathrm{Pa}_{\mathrm{CO}_{2}}$ decrement was not so marked as with acetazolamide, the postdrug HVR test was conducted only once with $\mathrm{PET}_{\mathrm{CO}_{2}}$ kept at a moderate hypocapnic level.

In two different subjects, arterial blood samples were repeatedly obtained during the $\mathrm{CO}_{2}$ rebreathing period. The procedures were conducted before and 4 days after acetazolamide $(500 \mathrm{mg})$ or $\mathrm{NH}_{4} \mathrm{Cl}(8 \mathrm{~g})$ administration, respectively. Thus, the relationships between arterial $\left[\mathrm{H}^{+}\right]$and $\mathrm{P}_{\mathrm{CO}_{2}}$ during $\mathrm{CO}_{2}$ rebreathing were determined.

To examine the $\mathrm{CO}_{2}$ chemosensitivity at varying plasma bicarbonate levels, the HCVR test only $4 \mathrm{~h}$ after acetazolamide ingestion $(500 \mathrm{mg}$ ) was additionally performed on 6 subjects. 


\section{RESULTS}

Acetazolamide study

The effects of acetazolamide on arterial blood gases, ventilation, and metabolism are shown in Table 1. After acetazolamide administration, a significant decrease in $\left[\mathrm{HCO}_{3}^{-}\right]$was consistently observed by a mean of $7.0 \pm 2.0$ (S.D.) mM and $\mathrm{Pa}_{\mathrm{CO}_{2}}$ decreased by $7.1 \pm 3.9 \mathrm{mmHg}$. Arterial $\mathrm{pH}$ decreased significantly, and these findings indicated chronic metabolic acidosis. The $P \mathrm{a}_{\mathrm{O}_{2}}$ increased by a mean of $10.2 \mathrm{mmHg}$. The $\dot{V}_{\mathrm{I}}$ increased by $15.1 \%$, predominantly because of augmented $V \mathrm{~T}$ by $25.4 \%$. Mean inspiratory flow $\left(V \mathrm{~T} / T_{\mathrm{I}}\right)$ increased significantly, but no significant changes in $f, T_{\mathrm{I}}, T \mathrm{E}$, and duty cycle $\left(T_{\mathrm{I}} / T_{\mathrm{T}}\right)$ were seen. Acetazolamide administration elicited no significant changes in metabolic rates $\left(\dot{V}_{\mathrm{O}_{2}}\right.$ and $\left.\dot{V}_{\mathrm{CO}_{2}}\right)$ and pulmonary functions $\left(\mathrm{VC}, \mathrm{FEV}_{1.0 \%}, \mathrm{FRC}\right)$.

Changes in ventilatory response to $\mathrm{CO}_{2}$ and hypoxia are shown in Table 2 and Fig. 1. In the ventilatory response to $\mathrm{CO}_{2}$, the slope was significantly increased by acetazolamide, with the mean value of $\dot{V}_{\mathrm{I}}$ at $P_{\mathrm{ET}_{\mathrm{CO}_{2}}}=60 \mathrm{mmHg}$ being significantly increased by $90.1 \%$, thereby indicating the position of the $\mathrm{CO}_{2}$ ventilatory response line shifting to a lower $P_{\mathrm{CO}_{2}}$ range. Hypoxic ventilatory responses, when measured during acetazolamide-induced hypocapnia, were not significantly increased. However, the responses to hypoxia measured under pre-acetazolamide $P \mathrm{ET}_{\mathrm{CO}_{2}}$ levels

Table 1. Effects of acetazolamide on pulmonary functions, arterial blood gases, resting ventilation, and metabolism.

\begin{tabular}{lcccc}
\hline & $n$ & Before & After & $p$ \\
\hline $\mathrm{VC}(l)$ & 11 & $4.77 \pm 0.59$ & $4.68 \pm 0.71$ & N.S. \\
$\mathrm{FEV}_{1.0 \%}(\%)$ & 11 & $83.6 \pm 5.7$ & $85.5 \pm 6.7$ & N.S. \\
$\mathrm{FRC}(l)$ & 11 & $3.52 \pm 0.89$ & $3.22 \pm 0.75$ & N.S. \\
$\mathrm{pH}$ & 11 & $7.39 \pm 0.02$ & $7.33 \pm 0.02$ & $<0.001$ \\
$\mathrm{~Pa}_{\mathrm{CO}_{2}}(\mathrm{mmHg})$ & 11 & $38.8 \pm 2.2$ & $31.8 \pm 3.4$ & $<0.001$ \\
$\mathrm{~Pa}_{\mathrm{O}_{2}}(\mathrm{mmHg})$ & 11 & $94.7 \pm 7.3$ & $104.8 \pm 8.6$ & $<0.05$ \\
{$\left[\mathrm{HCO}-\mathrm{CO}_{3}^{-}\right](\mathrm{mM})$} & 11 & $23.6 \pm 1.3$ & $16.5 \pm 1.4$ & $<0.001$ \\
$\mathrm{~A}-\mathrm{a} D_{\mathrm{O}_{2}}(\mathrm{mmHg})$ & 11 & $8.5 \pm 5.2$ & $6.7 \pm 5.5$ & N.S. \\
$\dot{V}_{\mathrm{I}}(l / \mathrm{min})$ & 7 & $7.79 \pm 0.98$ & $8.97 \pm 1.26$ & $<0.05$ \\
$V_{\mathrm{T}}(l)$ & 7 & $0.59 \pm 0.16$ & $0.74 \pm 0.16$ & $<0.01$ \\
$T_{\mathrm{I}}(\mathrm{s})$ & 7 & $1.68 \pm 0.51$ & $1.83 \pm 0.44$ & N.S. \\
$T_{\mathrm{E}}(\mathrm{s})$ & 7 & $2.94 \pm 1.16$ & $3.17 \pm 0.69$ & N.S. \\
$V_{\mathrm{T}} / T_{\mathrm{I}}(l / \mathrm{s})$ & 7 & $0.35 \pm 0.05$ & $0.42 \pm 0.06$ & $<0.01$ \\
$T_{\mathrm{I}} / T \mathrm{~T}$ & 7 & $0.37 \pm 0.04$ & $0.36 \pm 0.04$ & N.S. \\
$f(\mathrm{breaths} / \mathrm{min})$ & 7 & $14.4 \pm 4.8$ & $12.6 \pm 2.9$ & N.S. \\
$\dot{V}_{\mathrm{O}_{2}}(\mathrm{ml} / \mathrm{min})$ & 5 & $247 \pm 37$ & $235 \pm 38$ & N.S. \\
$\dot{V}_{\mathrm{CO}}(\mathrm{ml} / \mathrm{min})$ & 5 & $224 \pm 22$ & $229 \pm 42$ & N.S. \\
\hline
\end{tabular}

Values are mean \pm S.D. N.S., not significant $(p>0.05)$. 
Table 2. Effects of acetazolamide on ventilatory responses to $\mathrm{CO}_{2}$ and hypoxia.

\begin{tabular}{cccccc}
\hline & $n$ & Before & & After & $p$ \\
\hline $\begin{array}{c}\Delta \dot{V}_{\mathrm{I}} / \Delta P \mathrm{ET}_{\mathrm{CO}_{2}} \\
\left(l \cdot \mathrm{min}^{-1} \cdot \mathrm{mmHg}^{-1}\right)\end{array}$ & 11 & $1.53 \pm 0.67$ & & $2.30 \pm 1.00$ & $<0.001$ \\
$\quad \dot{V}_{\mathrm{I} \text { at } P \mathrm{ET}_{\mathrm{CO}_{2}}=60 \mathrm{mmHg}}$ & 11 & $22.2 \pm 9.1$ & & $42.2 \pm 16.3$ & $<0.001$ \\
$\left(l \cdot \mathrm{min}^{-1}\right)$ & & & & & \\
$\Delta \dot{V} \mathrm{I} / \Delta S \mathrm{a}_{\mathrm{O}_{2}}$ & 7 & $-0.38 \pm 0.29$ & $(\mathrm{H})$ & $-0.38 \pm 0.52$ & N.S. \\
$\left(l \cdot \mathrm{min}^{-1} \cdot \%-1\right)$ & 7 & $-0.30 \pm 0.13$ & $(\mathrm{~N})$ & $-0.98 \pm 0.66$ & $<0.02$ \\
$\dot{V} \mathrm{I}$ at $S \mathrm{a}_{\mathrm{O}_{2}}=75 \%$ & 7 & $16.1 \pm 6.2$ & $(\mathrm{H})$ & $17.7 \pm 14.6$ & N.S. \\
$\left(l \cdot \mathrm{min}^{-1}\right)$ & 7 & $14.2 \pm 3.6$ & $(\mathrm{~N})$ & $36.2 \pm 16.5$ & $<0.01$ \\
\hline
\end{tabular}

$(\mathrm{H})$, hypocapnic hypoxic response; $(\mathrm{N})$, normocapnic hypoxic response. Values are mean \pm S.D. N.S., not significant $(p>0.05)$.

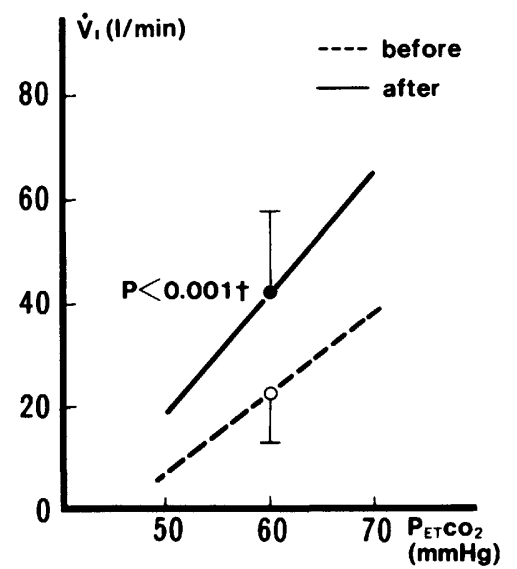

$t$ Comparison between $\dot{V}_{1}$ values at $\mathrm{P}_{\mathrm{ET}} \mathrm{CO}_{2} 60 \mathrm{mmHg}$ before and after acetazolamide

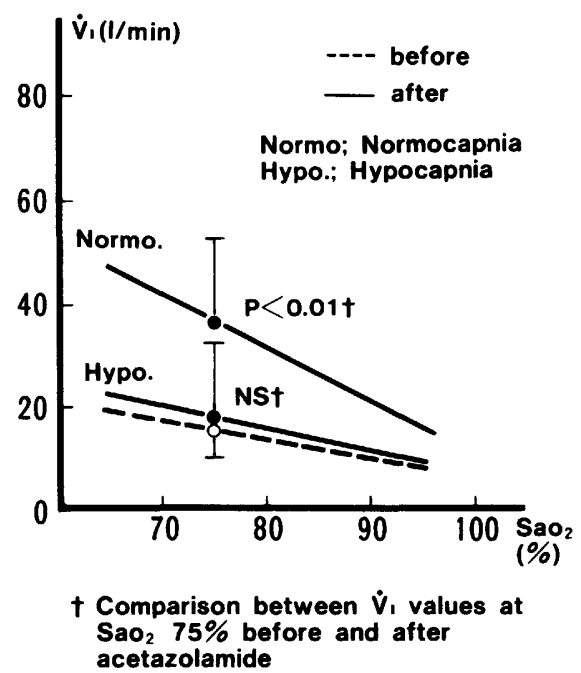

Fig. 1. Effects of acetazolamide on ventilatory responses to $\mathrm{CO}_{2}$ and hypoxia. The HCVR line (left panel) was drawn from the average of 11 subjects and HVR line (right panel) was the average of 7 subjects. Magnitude of ventilatory response was also compared at $P_{\mathrm{ET}_{\mathrm{CO}}} 60 \mathrm{mmHg}$ and $S \mathrm{a}_{\mathrm{O}_{2}} 75 \%$ as explained in the figures. The HCVR significantly increased after drug ingestion. Hypocapnic HVR did not change but normocapnic HVR increased significantly after acetazolamide.

had increased significantly. Simultaneously; the mean value of $\dot{V}_{\mathrm{I}}$ at $S \mathrm{a}_{\mathrm{O}_{2}}=75 \%$ increased and the hypoxic response line shifted to a lower $S \mathrm{a}_{\mathrm{O}_{2}}$ level under the normocapnic condition. 
Table 3. Effects of $\mathrm{NH}_{4} \mathrm{Cl}$ on arterial blood gases, resting ventilation, and metabolism.

\begin{tabular}{lcccc}
\hline & $n$ & Before & After & $p$ \\
\hline $\mathrm{pH}$ & 6 & $7.38 \pm 0.01$ & $7.30 \pm 0.03$ & $<0.01$ \\
$\mathrm{~Pa}_{\mathrm{CO}_{2}}(\mathrm{mmHg})$ & 6 & $39.9 \pm 2.0$ & $36.3 \pm 1.1$ & $<0.02$ \\
$\mathrm{~Pa}_{\mathrm{O}_{2}}(\mathrm{mmHg})$ & 6 & $94.7 \pm 7.3$ & $98.4 \pm 2.7$ & N.S. \\
{$\left[\mathrm{HCO}_{3}^{-}\right](\mathrm{mM})$} & 6 & $23.5 \pm 1.3$ & $17.9 \pm 1.4$ & $<0.001$ \\
$\mathrm{~A}-\mathrm{a} D_{\mathrm{O}_{2}}(\mathrm{mmHg})$ & 6 & $7.3 \pm 7.1$ & $7.9 \pm 2.0$ & N.S. \\
$\dot{V}_{\mathrm{I}}(l / \mathrm{min})$ & 6 & $7.23 \pm 1.49$ & $8.83 \pm 1.01$ & $<0.05$ \\
$V \mathrm{~T}(l)$ & 6 & $0.56 \pm 0.06$ & $0.59 \pm 0.08$ & N.S. \\
$T \mathrm{I}(\mathrm{s})$ & 6 & $1.77 \pm 0.53$ & $1.42 \pm 0.42$ & N.S. \\
$T \mathrm{E}(\mathrm{s})$ & 6 & $3.07 \pm 0.62$ & $2.47 \pm 0.79$ & $<0.05$ \\
$V \mathrm{~T} / T \mathrm{~T}(l / \mathrm{s})$ & 6 & $0.35 \pm 0.10$ & $0.42 \pm 0.09$ & N.S. \\
$T_{\mathrm{I}} / T \mathrm{~T}$ & 6 & $0.36 \pm 0.05$ & $0.36 \pm 0.06$ & N.S. \\
$f(\mathrm{breaths} / \mathrm{min})$ & 6 & $13.0 \pm 3.0$ & $15.7 \pm 3.2$ & $<0.05$ \\
$\dot{V}_{\mathrm{O}_{2}}(\mathrm{ml} / \mathrm{min})$ & 6 & $276 \pm 36$ & $263 \pm 24$ & N.S. \\
$\dot{V}_{\mathrm{CO}_{2}}(\mathrm{ml} / \mathrm{min})$ & 6 & $242 \pm 52$ & $254 \pm 33$ & N.S. \\
\hline
\end{tabular}

Values are mean \pm S.D. $\quad$ N.S., not significant $(p>0.05)$.

Table 4. Effects of $\mathrm{NH}_{4} \mathrm{Cl}$ on ventilatory responses to $\mathrm{CO}_{2}$ and hypoxia.

\begin{tabular}{|c|c|c|c|c|}
\hline & $n$ & Before & After & $p$ \\
\hline $\begin{array}{l}\Delta \dot{V}_{\mathrm{I} / \Delta P_{\mathrm{ET}} \mathrm{CO}_{2}} \\
\quad\left(l \cdot \mathrm{min}^{-1} \cdot \mathrm{mmHg}^{-1}\right)\end{array}$ & 6 & $1.80 \pm 0.84$ & $2.39 \pm 0.92$ & $<0.02$ \\
\hline $\begin{array}{l}\dot{V} \dot{V}_{\mathrm{I}} \text { at } P \mathrm{ETT}_{\mathrm{CO}_{2}}=60 \mathrm{mmHg} \\
\quad\left(l \cdot \mathrm{min}^{-1}\right)\end{array}$ & 6 & $22.3 \pm 10.4$ & $\begin{array}{c}30.3 \pm 10.6 \\
\text { (hypocapnic) }\end{array}$ & $<0.001$ \\
\hline $\begin{array}{l}\Delta \dot{V} \mathrm{I}_{\mathrm{l}} / \Delta S \mathrm{a}_{\mathrm{O}_{2}} \\
\quad\left(\mathrm{l} \cdot \min ^{-1} \cdot \% \%^{-1}\right)\end{array}$ & 5 & $0.27 \pm 0.11$ & $0.57 \pm 0.10$ & $<0.01$ \\
\hline $\begin{array}{l}\dot{V}_{\mathrm{I}} \text { at } S \mathrm{a}_{\mathrm{O}_{2}}=75 \% \\
\quad\left(l \cdot \min ^{-1}\right)\end{array}$ & 5 & $13.2 \pm 2.2$ & $19.3 \pm 4.6$ & $<0.01$ \\
\hline
\end{tabular}

Values are mean \pm S.D. N.S., not significant $(p>0.05)$.

\section{$\mathrm{NH}_{4} \mathrm{Cl}$ study}

Table 3 demonstrates the change in arterial blood gases, resting ventilation, and metabolism before and after $\mathrm{NH}_{4} \mathrm{Cl}$ administration. Quite similar to acetazolamide, $\left[\mathrm{HCO}_{3}^{-}\right]$fell by $5.6 \pm 1.8$ (S.D.) $\mathrm{mm}$ and $\mathrm{Pa}_{\mathrm{CO}_{2}}$ fell by $3.6 \pm 2.5 \mathrm{mmHg}$. Arterial pH decreased significantly from $7.38 \pm 0.01$ to $7.30 \pm 0.03 . P \mathrm{a}_{\mathrm{O}_{2}}$ increased by a mean of $3.7 \mathrm{mmHg}$, but this was not statistically significant. $\dot{V}_{\mathrm{I}}$ increased by $22.1 \%$, predominantly because of an augmented respiratory frequency with a significant shortening in $T \mathrm{E}$. The $\dot{V}_{\mathrm{I}}$ and $V \mathrm{~T} / T_{\mathrm{I}}$ showed an increasing tendency, but this was 


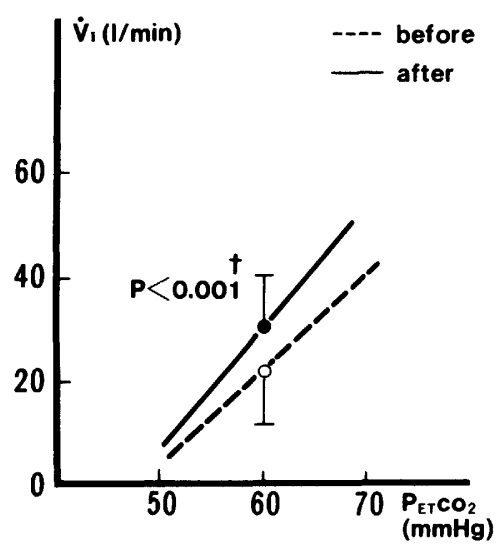

+ Comparison between $\dot{V}_{1}$ values at $\mathrm{PErCO}_{2} 60 \mathrm{mmHg}$ before and after $\mathrm{NH}_{4} \mathrm{Cl}$

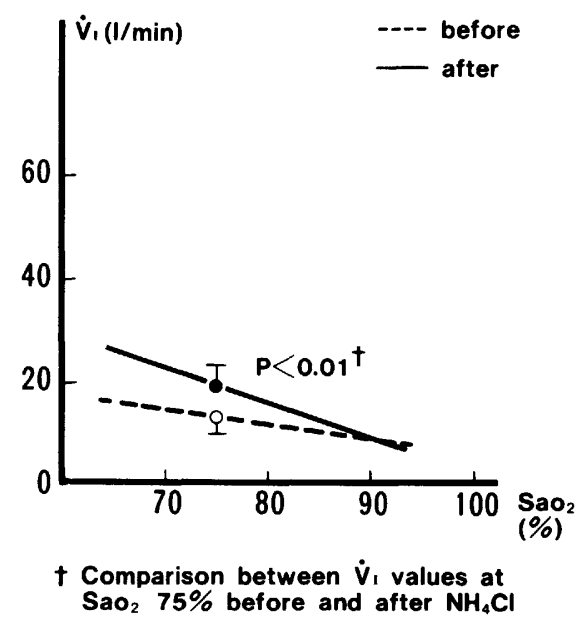

Fig. 2. Effects of $\mathrm{NH}_{4} \mathrm{Cl}$ on ventilatory responses to $\mathrm{CO}_{2}$ and hypoxia. Both $\mathrm{HCVR}$ (left panel) and HVR (right panel) increased significantly after drug administration.

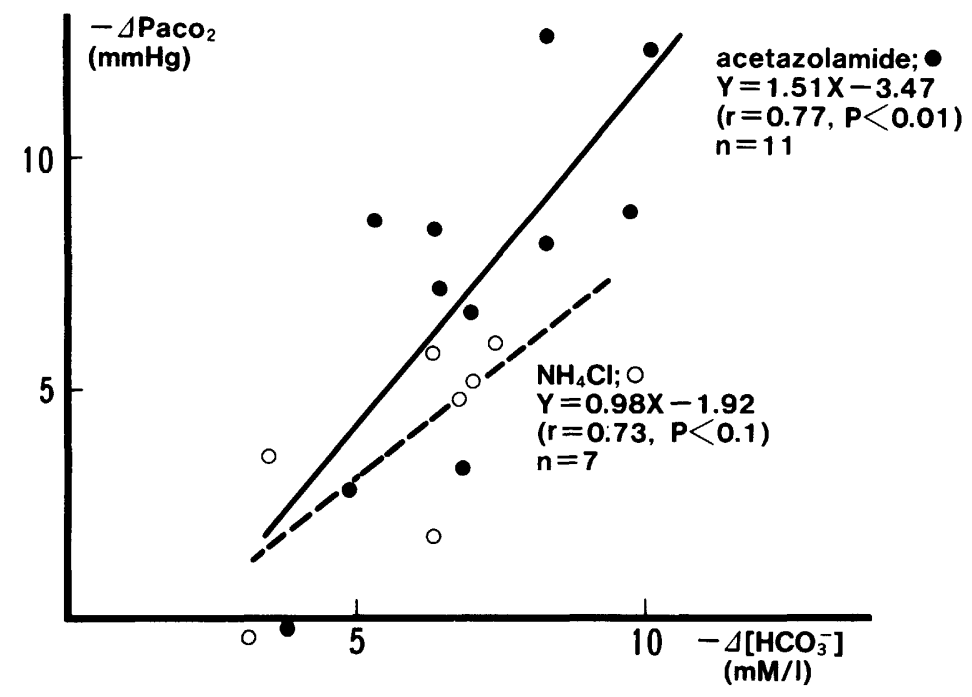

Fig. 3. Comparison of acetazolamide to $\mathrm{NH}_{4} \mathrm{Cl}$ ingestion in a steady-state relationship between changes in $\mathrm{Pa}_{\mathrm{CO}_{2}}$ and $\left[\mathrm{HCO}_{3}^{-}\right]$. The $\Delta \mathrm{Pa}_{\mathrm{CO}_{2}} / \Delta\left[\mathrm{HCO}_{3}^{-}\right]$slope was found steeper in acetazolamide than in $\mathrm{NH}_{4} \mathrm{Cl}$ administration.

not statistically significant. No remarkable changes in metabolic rates $\left(\dot{V}_{\mathrm{O}_{2}}\right.$ and $\left.\dot{V}_{\mathrm{CO}_{2}}\right)$ were seen.

The ventilatory responses to $\mathrm{CO}_{2}$ and hypoxia expressed as the slopes of $P_{\mathrm{ET}_{\mathrm{CO}}}{ }^{-}$or $\mathrm{Sa}_{\mathrm{O}_{2}}-\dot{V}_{\mathrm{I}}$ response lines are shown in Table 4 and Fig. 2 . In the $\mathrm{CO}_{2}$ response study, the change of the slope $\left(\Delta \dot{V} \mathrm{I} / \Delta P_{\mathrm{ET}_{\mathrm{CO}_{2}}}\right)$ was significant and also the 
mean value of $\dot{V}_{\mathrm{I}}$ at $P \mathrm{ET}_{\mathrm{CO}_{2}}=60 \mathrm{mmHg}$ increased, indicating that the position of the $\mathrm{CO}_{2}$ response line had shifted to lower values of $P_{\mathrm{CO}_{2}}$. Hypoxic ventilatory response, when measured at an observed $P_{\mathrm{ET}_{\mathrm{CO}}}$ level, increased significantly with an upward shift of the response line after $\mathrm{NH}_{4} \mathrm{Cl}$ administration.

\section{Comparison between acetazolamide and $\mathrm{NH}_{4} \mathrm{Cl}$ studies}

Figure 3 shows a comparison between acetazolamide and $\mathrm{NH}_{4} \mathrm{Cl}$ in a steadystate relationship between changes in $\mathrm{Pa}_{\mathrm{CO}_{2}}$ and $\left[\mathrm{HCO}_{3}^{-}\right]$. Acetazolamide elicited a reduction in $\mathrm{Pa}_{\mathrm{CO}_{2}}$ that was larger in magnitude $\left(\Delta \mathrm{P}_{\mathrm{CO}_{2}} / \Delta\left[\mathrm{HCO}_{3}^{-}\right]=1.51\right)$ than that seen in $\mathrm{NH}_{4} \mathrm{Cl}$ induced metabolic acidosis $\left(\Delta \mathrm{P}_{\mathrm{CO}_{2}} / \Delta\left[\mathrm{HCO}_{3}^{-}\right]=0.98\right)$. Both drugs

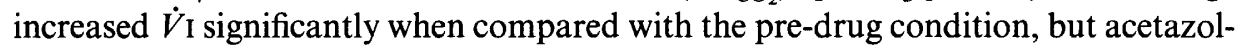
amide augmented $V \mathrm{~T}$ though $\mathrm{NH}_{4} \mathrm{Cl}$ increased $f$ predominantly.

In the ventilatory response to $\mathrm{CO}_{2}$, the increments in $\Delta \dot{V}_{\mathrm{I}} / \Delta P \mathrm{ET}_{\mathrm{CO}_{2}}$ and in $\dot{V}_{\mathrm{I}}$ at $P_{\mathrm{ET}_{\mathrm{CO}_{2}}} 60 \mathrm{mmHg}$ after drug administration were $0.77 \pm 0.51 \mathrm{l} \cdot \mathrm{min}^{-1} \cdot \mathrm{mmHg}^{-1}$ and $20.0 \pm 11.2 \mathrm{l} / \mathrm{min}$ with acetazolamide, and $0.59 \pm 0.40 \mathrm{l} \cdot \mathrm{min}^{-1} \cdot \mathrm{mmHg}$ and $8.0 \pm 2.8 \mathrm{l} / \mathrm{min}$ with $\mathrm{NH}_{4} \mathrm{Cl}$, respectively. Thus, acetazolamide elicited a stronger $\mathrm{CO}_{2}$ response than $\mathrm{NH}_{4} \mathrm{Cl}$ with a significant difference between the two drugs for the increment in $\dot{V}_{\mathrm{I}}$ at $P_{\mathrm{ET}_{\mathrm{CO}_{2}}} 60 \mathrm{mmHg}$.

On the other hand, hypoxic ventilatory responses both in terms of $\Delta \dot{V}_{\mathrm{I}} / \Delta S \mathrm{a}_{\mathrm{O}_{2}}$ and of $\dot{V}_{\mathrm{I}}$ at $\mathrm{Sa}_{\mathrm{O}_{2}} 75 \%$ significantly increased after $\mathrm{NH}_{4} \mathrm{Cl}$ but not acetazolamide ingestion. When $\mathrm{PET}_{\mathrm{CO}_{2}}$ increased up to the normocapnic level, HVR exceeded the pre-drug response in the acetazolamide administration.
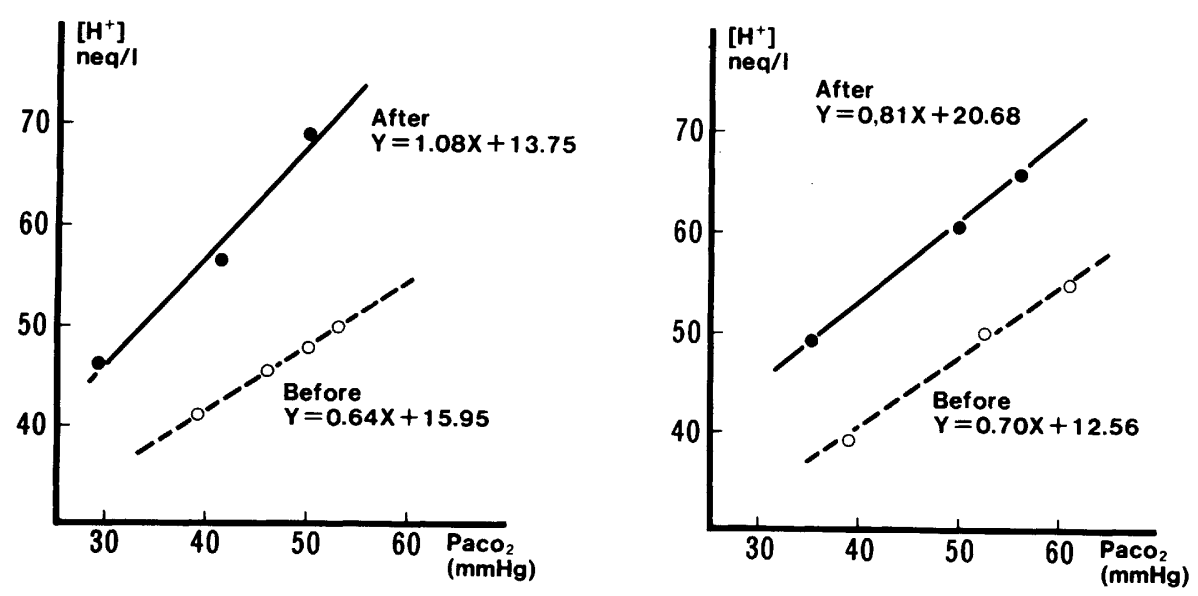

Fig. 4. Relationship between arterial $\left[\mathrm{H}^{+}\right]$and $\mathrm{Pa}_{\mathrm{CO}_{2}}$ during $\mathrm{CO}_{2}$ rebreathing before and after acetazolamide (left panel) and $\mathrm{NH}_{4} \mathrm{Cl}$ (right panel) administration. Linear $\mathrm{Pa}_{\mathrm{CO}_{2}}-\left[\mathrm{H}^{+}\right]$response line was observed. This response line became steeper after the ingestion of either drug, the degree being higher with acetazolamide than with $\mathrm{NH}_{4} \mathrm{Cl}$. 


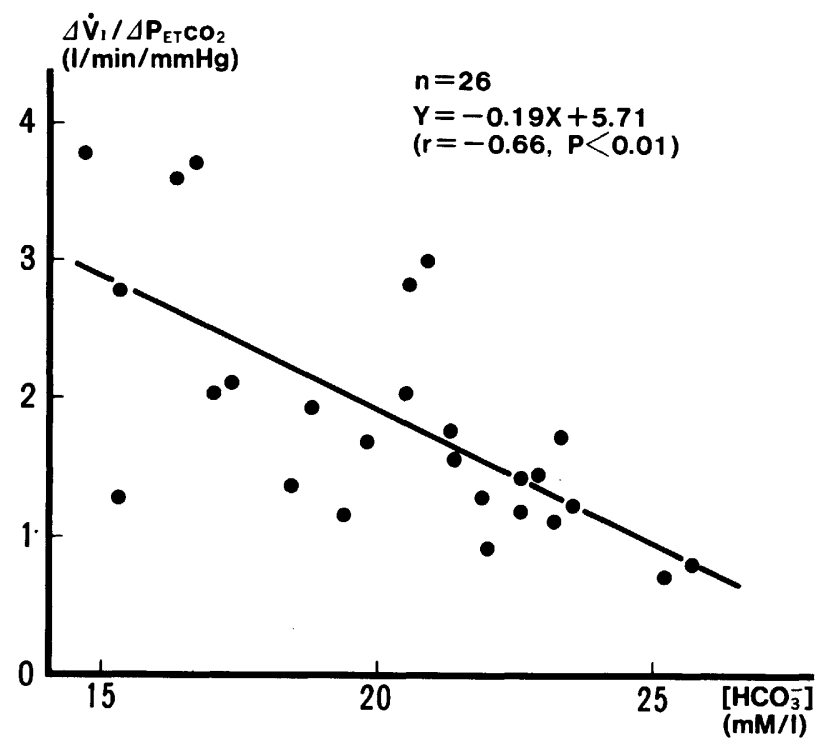

Fig. 5. Relationship between $\mathrm{CO}_{2}$-ventilation response slope and plasma bicarbonate concentration both before and $4 \mathrm{~h}$ or 4 days after acetazolamide administration. A significant inverse correlation was observed.

\section{$\left[\mathrm{H}^{+}\right]$during $\mathrm{CO}_{2}$ rebreathing}

Figure 4 shows the changes in plasma hydrogen ion concentration during $\mathrm{CO}_{2}$ rebreathing, before and after drug administration in two subjects. The increments in $\Delta\left[\mathrm{H}^{+}\right] / \Delta \mathrm{Pa}_{\mathrm{CO}_{2}}$ after acetazolamide and after $\mathrm{NH}_{4} \mathrm{Cl}$ were 0.44 and 0.11 $\mathrm{nEq} \cdot l^{-1} \cdot \mathrm{mmHg}^{-1}$, respectively. The changes in plasma bicarbonate concentration measured just before $\mathrm{CO}_{2}$ rebreathing were $7.9(23.7 \rightarrow 15.8) \mathrm{mEq} \cdot l^{-1}$ after acetazolamide and $6.8(24.6 \rightarrow 17.8) \mathrm{mEq} \cdot l^{-1}$ after $\mathrm{NH}_{4} \mathrm{Cl}$.

Relationship between $\mathrm{CO}_{2}$ chemosensitivity and $\left[\mathrm{HCO}_{3}^{-}\right]$in the acetazolamide study

Figure 5 demonstrates the relationship between the ventilatory response to $\mathrm{CO}_{2}$ and the bicarbonate concentration. The reduction in $\left[\mathrm{HCO}_{3}^{-}\right]$was induced by acetazolamide administration (after $4 \mathrm{~h}$ or 4 days). Significant inverse correlation between $\mathrm{CO}_{2}$ chemosensitivity and plasma bicarbonate concentration was observed.

\section{DISCUSSION}

In our results, acetazolamide and ammonium chloride differently affected the control of ventilation. The former predominantly augmented $V \mathrm{~T}$ and HCVR whereas the latter influenced $f$ and HVR.

Possible mechanisms for enhanced ventilatory activities by acetazolamide administration. The fact that $V \mathrm{~T}$ at rest and $\mathrm{CO}_{2}$ response were simultaneously 
increased by acetazolamide is in good agreement with the general concept in respiratory physiology (HALDANE et al., 1918; REBUCK et al., 1976). It has been shown by these authors that $\mathrm{CO}_{2}$ stimulus primarily caused an increased depth of breathing whereas hypoxic stimulus augmented respiratory frequency. Since $\mathrm{CO}_{2}$ stimulates ventilation via the central chemosensitive mechanism (LOESCHCKE, 1982), predominant increase in $V \mathrm{~T}$ and $\mathrm{CO}_{2}$ response may be explained by assuming that acetazolamide augments the activity of the central chemoreceptors. In the central nervous system, acetazolamide may inhibit $\mathrm{CO}_{2}$-hydration reaction, which plays an important role in mediating the rise in CSF $\left[\mathrm{HCO}_{3}^{-}\right]$(HASAN and KAZEMI, 1976; MAREN, 1979; JAVAHERI et al., 1984). These specific effects may enhance the activity of the central $\mathrm{CO}_{2}$ receptors.

Another factor to explain the elevated $\mathrm{CO}_{2}$ response is the acid-base displacement by acetazolamide. As shown in Fig. 3, the decrement in $\mathrm{Pa}_{\mathrm{CO}_{2}}$ for a given depression in plasma bicarbonate was larger with acetazolamide than with $\mathrm{NH}_{4} \mathrm{Cl}$, indicating the stronger ventilatory stimulus of the former. This finding was in accord with CHIESA et al. (1969). At the same time, the magnitude of $\left[\mathrm{HCO}_{3}^{-}\right]$ depression with acetazolamide was shown to be mostly larger than with $\mathrm{NH}_{4} \mathrm{Cl}$ administration. From the Henderson equation, $\left[\mathrm{H}^{+}\right]=K^{\prime} \cdot P_{\mathrm{CO}_{2}} /\left[\mathrm{HCO}_{3}^{-}\right]$, it can be expected that the magnitude of $\left[\mathrm{H}^{+}\right]$change for a given $P_{\mathrm{CO}_{2}}$ change will increase with a decreasing $\left[\mathrm{HCO}_{3}^{-}\right]$level. We found that this was indeed the case (Fig. 4). The $P_{\mathrm{CO}_{2}}-\left[\mathrm{H}^{+}\right]$response line became steeper with acetazolamide than with $\mathrm{NH}_{4} \mathrm{Cl}$. The higher plasma hydrogen ion concentration may stimulate either the peripheral or the central chemoreceptor mechanism (MITCHELL and SingER, 1965; LOESCHCKE, 1982).

Possible mechanism for enhanced ventilatory activities by ammonium chloride administration. Contrary to acetazolamide, $\mathrm{NH}_{4} \mathrm{Cl}$ predominantly increased the respiratory frequency at rest and hypoxic response. As described in the previous section, such characteristic features indicate augmented hypoxic chemosensitivity. Therefore, we assumed that $\mathrm{NH}_{4} \mathrm{Cl}$ primarily stimulated the peripheral chemoreceptors. HornBEIN and RoOs (1963) and GRAY (1968) demonstrated that the specific stimulus for these receptors was $\left[\mathrm{H}^{+}\right]$and not $P_{\mathrm{CO}_{2}}$. Whether or not the central chemosensitive structures are stimulated by metabolic acidosis is still controversial (MitChell and SingeR, 1965; Fencl et al., 1969; JAVAHERI et al., 1979). However, we were able to record augmented HVR with hypocapnia after $\mathrm{NH}_{4} \mathrm{Cl}$ ingestion. Since central chemosensitivity is primarily responsible for $\mathrm{CO}_{2}$ stimulation, our observation may signify the existence of well augmented activities of the peripheral chemoreceptors during $\mathrm{NH}_{4} \mathrm{Cl}$-induced metabolic acidosis.

HVR in acetazolamide administration became significantly elevated when $\mathrm{PET}_{\mathrm{CO}_{2}}$ was increased to the normocapnic level. However, since plasma bicarbonate markedly decreased, as shown in Table 1 and Fig. 3, the recovery of $P_{\mathrm{ET}_{\mathrm{CO}_{2}}}$ to the pre-drug value will result in overcompensation in blood $\left[\mathrm{H}^{+}\right]$. This can be explained by applying the Henderson equation represented before. Powles et al. (1980) reported that eucapnic $\mathrm{HVR}$ slope decreased and ventilation at $\mathrm{Sa}_{\mathrm{O}_{2}} 80 \%$ was 
unchanged after acetazolamide ingestion. They suggested that acetazolamide stimulated the central chemoreceptors and inhibited the peripheral ones.

\section{REFERENCES}

Chiesa, A., Stretton, T. B., Massoud, A. A. E., and Howell, J. B. L. (1969) The effects of inhibition of carbonic anhydrase with dichlorphenamide on ventilatory control at rest and on exercise in normal subjects. Clin. Sci., 37: 689-706.

Fencl, V., Vale, J. R., and Broch, J. A. (1969) Respiration and cerebral blood flow in metabolic acidosis and alkalosis in humans. J. Appl. Physiol., 27: 67-76.

GRAY, B. A. (1968) Response of the infused carotid body to changes in $\mathrm{pH}$ and $\mathrm{PCO}_{2}$. Respir. Physiol., 4: 229-245.

Haldane, J. S., Meakins, J. C., and Priestley, J. G. (1918) The respiratory response to anoxaemia. J. Physiol. (Lond.), 52: 420-432.

Harrington, J. T. and Cohen, J. J. (1982) Metabolic acidosis. In: Acid-Base, ed. by Cohen, J. J. and Kassiren, J. P., Little Brown, Boston, M. A., Chap. 8, p. 139.

HASAN, F. M. and KAZEMI, H. (1976) Dual contribution theory of regulation of CSF $\mathrm{HCO}_{3}^{-}$in respiratory acidosis. J. Appl. Physiol., 40: 559-567.

Hornbein, T. F. and Roos, A. (1963) Specificity of $\mathrm{H}$ ion concentration as a carotid chemoreceptor stimulus. J. Appl. Physiol., 18: 580-584.

JAVAHERI, S., HerRera, L., and KAZEMI, H. (1979) Ventilatory drive in acute metabolic acidosis. J. Appl. Physiol., 45: 913-918.

JAVAhERI, S., Weyne, J., Demeester, G., and Leusen, I. (1984) Effects of acetazolamide on ionic composition of cisternal fluid during acute respiratory acidosis. J. Appl. Physiol., 57: $85-91$.

LOESCHCKE, H. H. (1982) Review lecture. Central chemosensitivity and the reaction theory. J. Physiol. (Lond.), 332: 1-24.

Maren, T. H. (1967) Carbonic anhydrase: Chemistry, physiology and inhibition. Physiol. Rev., 47: 595-781.

MAREN, T. H. (1979) Effect of varying $\mathrm{CO}_{2}$ equilibra on rates of $\mathrm{HCO}_{3}^{-}$formation in cerebrospinal fluid. J. Appl. Physiol., 47: 471-477.

Mitchell, R. A. and Singer, M. M. (1965) Respiration and cerebrospinal fluid pH in metabolic acidosis and alkalosis. J. Appl. Physiol., 20: 905-911.

Peters, J. P., Jr. (1917) The response of the respiratory mechanism to rapid changes in the reaction of the blood. Am. J. Physiol., 44: 84-108.

Powles, A. C. P., Sutton, J. R., and RigG, J. R. A. (1980) Acetazolamide and the ventilatory response to hypoxia: Comparison of eucapnic and hypercapnic conditions. Am. Rev. Respir. Dis. (Suppl.), 121: 392.

RebuCK, A. S., RigG, J. R. A., and SAUNDERS, N. A. (1976) Respiratory frequency response to progressive isocapnic hypoxia. J. Physiol. (Lond.), 258: 19-31. 